\title{
Pengaruh Penambahan Fruktosa dalam Pengencer Air Kelapa Hijau Terhadap Motilitas Spermatozoa Sapi PO (Peranakan Onggole)
}

\author{
Effect of Addition of Fructose in Coconut Water Diluent to Motility of Ongole \\ Crossbreed Sperm
}

\author{
D. Muhammad ${ }^{1}$, N. Isnaini ${ }^{1}$, Kuswati ${ }^{1}$, A. P. A. Yekti ${ }^{1}$, Aryogi ${ }^{2}$, M. Luthfi ${ }^{2}$, \\ L. A. Sunarto ${ }^{2}$, dan T. Susilawati ${ }^{1}$ \\ ${ }^{1}$ Fakultas Peternakan Universitas Brawijaya Malang \\ Jl. Veteran Malang 65145 Jawa Timur \\ ${ }^{2}$ Loka Penelitian Sapi Potong \\ Grati, Pasuruan 67184 \\ Corresponding e-mail: dedi.pendidik@gmail.com, trinil_susilawati@yahoo.com
}

\begin{abstract}
Coconut water is a cheap material and can be an alternative material in the process of making semen diluent, because it contains several substances needed by sperm such as an energy source like fructose. This study aims to determine the effect of fructose addition in coconut water diluents to the motility of Ongole Crossbreed cattle. This study used semen from Ongole Crossbreed cattle which were collected using the artificial vaginal. The methodology used was an experimental laboratory design using a Randomized Completely Block Design. This research uses 3 treatments, $\mathrm{P} 1=$ Coconut water $+20 \%$ egg yolk, $\mathrm{P} 2=$ Coconut water $+20 \%$ egg yolk $+0.4 \%$ egg white + fructose $1 \mathrm{mg} / \mathrm{ml} . \mathrm{P} 3=$ Coconut $+20 \%$ egg yolk $+0.4 \%$ egg white $+2 \mathrm{mg} / \mathrm{ml}$ fructose. All treatments were repeated as 10 replications. The results showed that there was no significant difference in sperm motility and total motile sperm between the formulations of coconut water diluents (P1, P2, P3) during storage at $2-5^{\circ} \mathrm{C}$. Coconut water diluent are good at maintaining sperm motility and total motile sperm for the $5^{\text {th }}$ day.
\end{abstract}

Key words: coconut water, liquid semen, total motil sperm

\begin{abstract}
ABSTRAK
Air kelapa merupakan bahan lokal yang murah dan dapat menjadi bahan baku alternatif dalam proses pembuatan pengencer semen karena mengandung beberapa zat yang dibutuhkan oleh spermatozoa seperti sumber energi berupa fruktosa. Penelitian ini bertujuan untuk mengetahui pengaruh penambahan fruktosa dalam pengencer air kelapa hijau terhadap motilitas spermatozoa sapi PO (Peranakan Onggole). Penelitian ini menggunaan semen dari bangsa sapi Peranakan Ongole yang ditampung menggunakan metode vagina buatan. Metodologi yang digunakan adalah eksperimental laboratorium menggunakan rancangan acak kelompok (RAK). Penelitihan ini menggunakan 3 perlakukan, P1 $=$ Pengencer air kelapa + kuning telur $20 \%, \mathrm{P} 2=$ Pengencer air kelapa + kuning telur $20 \%+$ putih telur $0,4 \%+$ fruktosa $1 \mathrm{mg} / \mathrm{ml}$. P3 = Pengencer air kelapa +kuning telur $20 \%+$ putih telur $0,4 \%$ + fruktosa $2 \mathrm{mg} / \mathrm{ml}$ dengan 10 ulangan. Hasil memperlihatkan bahwa tidak terdapat perbedaan yang signifikan pada motilitas spermatozoa dan total spermatozoa motil antara formulasi pengencer air kelapa (P1, P2, P3) selama peyimpanan suhu $2-5{ }^{\circ} \mathrm{C}$. Pengencer air kelapa baik dalam menjaga motilitas spermatozoa dan total spermatozoa motil hingga hari ke lima.
\end{abstract}

Kata kunci: air kelapa, total motilitas motil, semen cair

\section{PENDAHULUAN}

Air kelapa merupakan bahan lokal yang murah dan dapat menjadi bahan baku alternatif dalam proses pembuatan pengencer semen. Kandungan karbohidrat sederhana dan mineral dalam pengencer yang diperlukan oleh spermatozoa dapat terpenuhi dari air kelapa. Vigliar et al. (2006) menyatakan bahwa air kelapa mengandung beberapa gula sederhana, misal: sukrosa, glukosa, dan fruktosa.

Hasil penelitian Mugiyati et al. (2017); Salim et al. (2018) menunjukkan 
bahwa penggunaan pengencer air kelapa dengan varietas yang bebreda mampu mempertahankan motilitas spermatozoa di atas $40 \%$ hingga hari kedua pada penyimpanan suhu 3-5 ${ }^{\circ} \mathrm{C}$. Sedangkan hasil penelitian Audia et al. (2017) yang menggunakan pengecer air kelapa hijau mampu menjaga motilitas spermatozoa diatas $40 \%$ sampai penyimpanan hari kedua selama penyimpanan pada suhu $3-5{ }^{\circ} \mathrm{C}$.

Penambahan pengenceran pada semen dapat menyebabkan berkurangnya konsentrasi zat-zat yang secara alami terdapat dalam plasma semen seperti sumber energi, lipit, protein dan ion-ion yang dapat merubah keseimbangan tekanan osmose pada pengencer sehingga mempengaruhi motilitas dan daya hidup (Adnani et al. (2012). Penambahan fruktosa sebagai sumber energi serta protein eksogenus berupa putih telur dalam pengencer air kelapa diharapkan dapat mensubstitusi beberapa zat yang hilang dari plasma semen akibat proses pengenceran sehingga dapat menunjang kehidupan spermatozoa.

Formulasi pengencer dengan bahandasar air kelapa dengan penambahan fruktosa sebagai sumber energi tambahan, putih telur sebagai makromolekul, dan kuning telur sebagai krioprotektan diharapkan dapat mempertahankan motilitas spermatozoa dan total spermatozoa motil sebaik mungkin. Berdasarkan uraian di atas perlu dilakukan penelitian tentang penggunaan pengencer air kelapa hijau terhadap motilitas spermatozoa sapi PO (Peranakan Onggole) selama penyimpanan.

\section{MATERI DAN METODE}

Penelitian dilaksanakan di Loka Penetilian Sapi Potong Grati Pasuruan dan Laboratorium Reproduksi Ternak Fakultas Peternakan Universitas Brawijaya pada bulan Februari - Maret 2018.

\section{Semen sapi}

Semen yang digunakan berasal dari sapi PO yang dipelihara di Loka Penetilian Sapi Potong Grati. Adapun kriteria semen yang layak untuk digunakan adalah motilitas massa minimal $2+$, motilitas individu $\geq 70 \%$. Semen ditampung menggunakan metode vagina buatan.

\section{Pengencer Air Kelapa}

Pengencer air kelapa dibuat dari air kelapa hijau (Cocos nucifera) dengan usia buah 5 sampai 8 bulan. Air kelapa terlebih dahulu disaring dengan kertas saring halus kemudian dipasteurisasi pada suhu $56{ }^{\circ} \mathrm{C}$ selama 20 menit dengan tujuan untuk menonaktifkan enzim-enzim pada air kelapa. Selanjutnya, ditambahkan NaHCO3 $1 \mathrm{mg} / \mathrm{ml}$, antibiotik penicillin $1 \mathrm{mg} / \mathrm{ml}$, streptomycin sulfate $1 \mathrm{mg} / \mathrm{ml}$, kuning telur ayam $20 \%$, dan sebagai perlakuan yaitu putih telur ayam 0,4\%, fruktosa $10 \mathrm{dan} 20 \mathrm{mg} / \mathrm{ml}$.

\section{Pengencer CEP-3}

Bahan pengencer CEP-3 terdiri dari $\mathrm{NaCl} 0,88 \mathrm{gr} / \mathrm{l} ; \mathrm{KCl} 0,52 \mathrm{gr} / 1 ; \mathrm{CaCl}_{2}\left(\mathrm{H}_{2} \mathrm{O}\right)_{2}$ $0,44 \mathrm{~g} / \mathrm{l} ; \mathrm{MgCl}_{2}\left(\mathrm{H}_{2} \mathrm{O}\right)_{6}$ 0,81 g/l; $\mathrm{NaHCO}_{3} 1$ $\mathrm{g} / \mathrm{l} ; \mathrm{NaH}_{2} \mathrm{PO}_{4} \quad 0,96 \mathrm{~g} / \mathrm{l} ; \mathrm{KH}_{2} \mathrm{PO}_{4} \quad 2,72 \mathrm{~g} / \mathrm{l}$; Fruktosa 9,9 g/l; Sorbitol $1 \mathrm{~g} / 1$; Tris Aminomethan 16,19 g/l; Gentamicin 0,05 g/l; Asam Sitrat 8,24 g/l. Bahan-bahan dicampur hingga menghasilkan osmolaritas $320 \mathrm{mOsm}$ dan $\mathrm{pH}$ 6,6. Pengencer CEP-3 ditambahkan kuning telur segar (umur $<3$ hari) dengan 20 $\%$ dan putih telur $0,4 \%$.

\section{Rancangan Penelitian}

Penelitian ini menggunaan metode eksperimental laboratorium dengan menggunakan Rancangan Acak Kelompok (RAK). Pengelompokan pada penelitian ini dilakukan berdasarkan waktu penampungan yang berbeda. Adapun perlakuan dalam penelitian ini terdiri dari 3 perlakukan dan 10 ulangan. $\mathrm{P} 1=$ Pengencer air kelapa $+20 \%$ kuning telur. $\mathrm{P} 2=$ Pengencer air kelapa + $20 \%$ kuning telur $+0,4 \%$ putih telur + fruktosa $1 \mathrm{mg} / \mathrm{ml}$. P3 = Pengencer air kelapa $+20 \%$ kuning telur $+0,4 \%$ putih telur + fruktosa $2 \mathrm{mg} / \mathrm{ml}$.

\section{Pengamatan Motilitas Spermatozoa}

Pengamatan motilitas individu spermatozoa diamati menggunakan mikroskop cahaya dengan perbesaran 400 
kali, kemudian dilakukan pengamatan spermatozoa yang bergerak secara progresif (Garner and Hafez, 2008).

\section{Analisis Data}

Data penelitian dianalisa menggunakan analisis varian (ANOVA) dan kemudian dilakukan pengujian lanjut menggunakan Uji Jarak Berganda Duncan (Duncan's Multiple Range Test). Pada akhir waktu penyimpanan yang nilai persentase motilitasnya sekitar $40 \%$ dilakukan uji $C h i$ squere untuk menentukan kesesuaian motilitas akhir dengan nilai harapan.

\section{HASIL DAN PEMBAHASAN}

\section{Kualitas Semen Sapi PO}

$\begin{array}{lll}\text { diencerkan } & \text { meliputi } & \text { pemeriksaan }\end{array}$ makroskopis dan pemeriksaan mikroskopis. Pemeriksaan makroskopis terdiri dari warna, volume, $\mathrm{pH}$, dan konsistensi spermatozoa. Pemeriksaan mikroskopis yang meliputi motilitas massa, motilitas individu, viabilitas, abnormalitas, konsentrasi. Rataan dan simpangan baku kualitas semen sapi PO ditunjukkan padaTabel 1.

Rata-rata volume semen dari sapi PO yang digunakan untuk penelitian adalah 4,00 $\pm 1,41 \mathrm{ml}$. Hasil tersebut tergolong rendah jika dibandingkan dengan yang dilaporkan oleh Garner and Hafez (2008) bahwa volume semen sapi dalam penampungan sekirat 5-8 ml.Warna semen sapi PO yang diperoleh adalah putih susu. Susilawati (2011) menjelaskan bahwa semen sapi pada umumnya berwarna putih kekuning-kuningan atau hampir seputih susu. Adapun rata-rata $\mathrm{pH}$ semen yang didapatkan adalah $6,50 \pm$ 0,12. Hasil penampungan tersebut menunukkan bahwa $\mathrm{pH}$ semen yang digunakan adalah normal. Sebagaimana yang disampaikan oleh Ax et al. (2008) bahwa pH semen sapi antara 6,4 sampai 7,8.

Rata-rata motilitas massa semen sapi PO yang digunakan dalam penelitian adalah $2+$. Persyaratan motilitas massa agar semen dapat diproses minimal 2+ (Ducha et al., 2013. Rata-rata motilitas individu semen segar sapi PO yang digunakan adalah 71,25 \pm 2,50\%. Muhammad et al. (2016) menyampaikan bahwa syarat minimal motilitas semen untuk dilakukan pengencerkan adalah $70 \%$. Konsentrasi spermatozoa semen sapi PO yang digunakan adalah $1245,00 \pm 184,30 \mathrm{juta} / \mathrm{ml}$. Garner dan Hafez (2008) bahwa konsentrasi semen sapi bervariasi dari 1.000-1.800 juta spermatozoa setiap mililiter.

Rata-rata viabilitas spermatozoa sapi PO yang digunakan dalam penelitian ini adalah $92,31 \pm 2,67 \%$. Hal tersebut menunjukkan bahwa semen sapi PO yang digunakan termasuk memenuhi syarat untuk dilakukan proses selanjutnya. Ducha et al (2013) yang menyampaikan bahwa semen yang akan diencerkan harus memiliki viabilitas minimal $70 \%$.

Tabel 1. Rata-rata kualitas semen sapi PO yang digunakan dalam penelitian

\begin{tabular}{lc}
\hline Parameter & Rata-rata \pm sd \\
\hline Makroskopis & \\
Volume per ejakulat (ml) & $4,00 \pm 1,41$ \\
Warna & Putih susu \\
pH & $6,50 \pm 0,12$ \\
Konsistensi & Sedang - kental \\
\hline Mikroskopis & $2+$ \\
Motilitas massa & $71,25 \pm 2,50$ \\
Motilitas individu (\%) & $92,31 \pm 2,67$ \\
Viabilitas (\%) & $2,60 \pm 0,78$ \\
Abnormalitas (\%) & $1245,00 \pm 184,30$ \\
Konsentrasi (juta/ml) & $886,75 \pm 129,85$ \\
Total spermatozoa motil & \\
\hline
\end{tabular}


Rata-rata persentase abnormalitas semen sapi PO yang digunakan dalam penelitian adalah $2,60 \pm 0,78 \%$. Nilai tersebut menunjukkan bahwa semen sapi PO yang digunakan memiliki kategori yang baik. Ismaya (2014) menyampaikan bahwa semen termasuk jelek dan daya fertilisasinya rendah jika persentase abnormalitasnya lebih dari $20 \%$.

\section{Motilitas Spermatozoa}

Motilitas spermatozoa menunjukkan nilai spermatozoa yang bergerak progresif kearah depan. Rata-rata dan simpang baku motilitas spermatozoa dari sapi PO dengan berbagai formulasi pengencer air kelapa ditunjukkan pada Tabel 2.

Hasil analisis ragam motilitas spermatozoa sapi PO dalam formulasi pengencer air kelapa yang berbeda selama disimpan dalam suhu $2-5{ }^{\circ} \mathrm{C}$ menunjukkan pada hari penyimpanan ke-5 sampai ke-6 menunjukkan tidak terdapat perbedaan yang nyata $(\mathrm{P}>0,05)$ antara perlakuan $\mathrm{P} 1, \mathrm{P} 2$, dan P3.

Hasil uji Chi square terhadap motilitas spermatoza pada penyimpana hari ke-5 menunjukkan sesuai dengan nilai harapan dan nilai SNI yaitu diatas 40\%, sedangkan pada penyimpanan hari ke-6 menunjukkan nilai yang berbeda dengan nilai harapan maupun SNI. Penelitian ini menunjukkan hasil yang lebih tinggi dibandingkan dengan penelitian Aziz et al. (2018); Salim et al. (2018) yang melaporkan bahwa pengecer air kelapa mampu menjaga motilitas spermatoza hingga penyimpanan hari ke dua.

Antar perlakuan penambahan fruktosa pada pengencer air kelapa (P1, P2, P3) dengan proporsi yang berbeda dimana menunjukkan hasil yang tidak berbeda. Hal tersebut diduga karena kebutuhan energi spermatozoa berupa Adenosine Triphosphate (ATP) dalam mempertahankan hidup secara alami telah terpenuhi didalam plasma semen dan kandungan fruktosa yang ada dalam air kelapa. Jika selama peyimpanan hingga hari ke 6 kebutuhan sumber energi spermatozoa sudah terpenuhi dari plasma semen dan air kepala maka penambahan fruktosa tidak akan memberikan pengaruh yang nyata terhadap motilitas spermatozoa. Susilawati (2011) menjelaskan bahwa fruktosa adalah gula dasar dari seminal. Fruktosa termasuk sumber energi yang sangat baik bagi spermatozoa dikarenakan jalur metobolisme yang lebih pendek yaitu melalui proses fruktoliasis.

$$
\text { Grafik pada Gambar } 1
$$

memperlihatkan bahwa perlakuan pengencer yang berbasis air kelapa (P1, P2, dan P3) meskipun dalam hal menjaga motilitas spermatozoa masih tergolong singkat, akantetapi air kelapa berpotensi untuk dikembangkan menjadi pengencer semen dengan kualitas yang baik. Hal tersebut karena air kelapa merupakan bahan yang mudah didapat, harganya murah dan yang paling penting adalah mampu mempertahankan kualitas spermatozoa. Farapati dan Sayogo (2014) menyatakan bahwa air kelapa dapat menjadi bahan pengencer alternatif yang mudah didapatkan karena banyak tersedia di lingkungan sekitar dan harganya terjangkau. Kandungan air kelapa berbeda-beda tergantung varietas, umur dan faktor iklim.

Tabel 2. Rata-rata motilitas spermatozoa sapi PO selama penyimpanan pada suhu $2-5{ }^{\circ} \mathrm{C}$

\begin{tabular}{crrcccccc}
\hline \multirow{2}{*}{ Perlakuan } & \multicolumn{7}{c}{ Rata-rata motilitas selama penyimpanan (\%) \pm Simpang baku } \\
\cline { 2 - 9 } & \multicolumn{1}{c}{ H1 } & \multicolumn{1}{c}{ H2 } & H3 & H4 & H5 & H6 & H7 & H8 \\
\hline P1 & $70,0 \pm 0,0$ & $69,29 \pm 1,89$ & $67,14 \pm 3,93$ & $65,71 \pm 4,50$ & $54,29 \pm 9,32$ & $36,43 \pm 6,27$ & $27,86 \pm 10,35$ & $4,29 \pm 5,35$ \\
P2 & $70,71 \pm 1,89$ & $69,29 \pm 1,89$ & $66,43 \pm 3,78$ & $65,70 \pm 4,45$ & $57,14 \pm 7,56$ & $39,29 \pm 4,50$ & $27,86 \pm 8,59$ & $6,43 \pm 3,78$ \\
P3 & $71,43 \pm 2,44$ & $67,86 \pm 2,67$ & $67,14 \pm 3,93$ & $65,70 \pm 4,45$ & $56,43 \pm 6,90$ & $38,57 \pm 5,56$ & $27,14 \pm 9,94$ & $6,43 \pm 2,44$
\end{tabular}

Keterangan: : $\mathrm{P}=$ Perlakuan, $\mathrm{H}=$ Hari penyimpanan. Tidak terdapat perbedaan yang nyata $(\mathrm{P}>0,05)$ 
Kewilaa et al (2014) menegaskan bahwa air kelapa adalah salah satu bahan yang biasa digunakan untuk pengencer semen yang memenuhi kriteria, karena buah kelapa di negara-negara tropis seperti Indonesia sangat mudah diperoleh dengan harga murah dibandingkan dengan bahanbahan kimia sintetik.

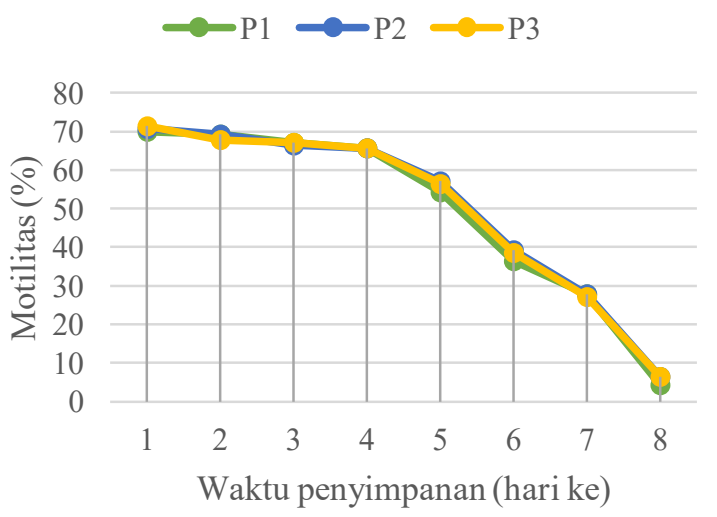

Gambar1. Grafik motilitas spermatozoa sapi PO dalam berbagai formulasi pengencer air kelapa selama penyimpanan pada suhu $2-5^{\circ} \mathrm{C}$.

\section{Total Spermatozoa Motil}

Total spermatozoa motil merupakan hasil perkalian antara konsentrasi spermatozoa dengan motilitas spermatozoa dalam suatu semen cair. Hal ini sesuai dengan Nikbakht dan Saharkhiz (2011) yang menyatakan bahwa jumlah spermatozoa motil dapat dihitung dengan mengalikan konsentrasi spermatozoa dengan spermatozoa yang motil progresif. Apabila total spermatozoa yang motil diketahui, maka dapat diketahui pula apakah semen cair yang digunakan memenuhi syarat untuk inseminasi buatan. Rata-rata total spermatozoa yang motil pada penyimpanan hingga hari ke-8 dapat dilihat pada Tabel 3 .

Hasil analisis ragam nilai total spermatozoa motil antar formulasi pengencer yang berbeda pada bangsa sapi PO menunjukkan tidak terdapat perbedaan yang nyata $(\mathrm{P}>0,05)$ pada penyimpanan hingga hari ke-8. Rata-rata nilai total spermatozoa motil antar formulasi pengencer air kelapa yang berbeda (P1, P2, P3) pada bangsa sapi PO dari nilai terbesar hingga terkecil pada penyimpanan hingga hari ke-5 berturut-turut adalah P2 sebesar 66,8 juta/ml, P1 sebesar 65,8 juta/ml, P3 sebesar 65,4 juta/ml. Ratarata nilai total spermatozoa motil dari semua perlakuan (P1, P2, P3) hingga penyimpanan hari ke-5 masih menunjukkan hasil yang baik yaitu diatas 40 juta $/ \mathrm{ml}$. Standar $40 \mathrm{juta} / \mathrm{ml}$ ditentukan berdasarkan dari standart persentase motilitas spermatozoa untuk digunakan dalam IB yaitu $40 \%$, kemudian dikalikan dengan standart konsentrasi spermatozoa minimal untuk semen yang digunakan IB yaitu 25 juta/ministraw atau setara dengan $100 \mathrm{juta} / \mathrm{ml}$. Muhammad et al. (2016) menyatakan bahwa nilai total spermatozoa motil semen yang digunakan untuk IB minimal 40 juta/ $\mathrm{ml}$.

Tabel 3. Rata-rata total spermatozoa motil sapi PO selama penyimpanan pada suhu $2-5{ }^{\circ} \mathrm{C}$

\begin{tabular}{ccccccccc}
\hline \multirow{2}{*}{ Perlakuan } & \multicolumn{7}{c}{ Rata-rata total spermatozoa motil (Juta/ml) \pm Simpang baku } \\
\cline { 2 - 9 } & H1 & H2 & H3 & H4 & H5 & H6 & H7 & H8 \\
\hline P1 & $80,5 \pm 1,7$ & $79,5 \pm 9,4$ & $77,2 \pm 9,8$ & $75,9 \pm 9,2$ & $65,8 \pm 14,2$ & $42,8 \pm 8,6$ & $31,5 \pm 12,4$ & $7,0 \pm 7,7$ \\
P2 & $80,4 \pm 1,1$ & $79,2 \pm 3,3$ & $76,4 \pm 4,8$ & $75,2 \pm 5,0$ & $66,8 \pm 9,5$ & $44,5 \pm 4,9$ & $31,3 \pm 7,9$ & $7,4 \pm 3,8$ \\
P3 & $80,9 \pm 1,5$ & $78,2 \pm 10,6$ & $76,4 \pm 10,6$ & $74,4 \pm 7,6$ & $65,4 \pm 10,6$ & $43,0 \pm 9,1$ & $30,3 \pm 8,2$ & $6,8 \pm 2,3$ \\
\hline
\end{tabular}

Keterangan: : $\mathrm{P}=$ Perlakuan, $\mathrm{H}=$ Hari penyimpanan. Tidak terdapat perbedaan yang nyata $(\mathrm{P}>0,05)$ 


\section{KESIMPULAN}

1) Tidak terdapat pengaruh yang signifikan pada penambahan fruktosa dalam pengencer air kelapa terhadap motilitas spermatozoa sapi PO selama penyimpanan pada suhu $2-5^{\circ} \mathrm{C}$.

2) Pengencer berbasis air kelapa dengan berbagai formulasi mampu mempertahankan motilitas diatas $40 \%$ hingga hari ke-5.

\section{UCAPAN TERIMAKASIH}

Kemenristek DIKTI memberikan dana dengan skema PUPTN serta LPDP (Lembaga Pengelolah Dana Pendidikan) melalui program BPI. Terima kasih juga disampaikan kepada Loka Penelitian Sapi Potong Grati yang telah memberikan fasilitas penelitian.

\section{DAFTAR PUSTAKA}

Adnani, L. P. D. H, W. Bebas, M. K. Budiasa. 2012. Penambahan bovine serum albumin pada pengencer kuning telur terhadap motilitas dan daya hidup spermatozoa anjing. Indonesia Medicus Veterinus. 1 (4): $519-529$.

Audia, R. P., M. A. Salim, N. Isnaini dan T. Susilawati. 2017. Pengaruh perbedaan kematangan air kelapa hijau sebagai bahan pengencer yang ditambah $10 \%$ kuning telur terhadap kualitas semen cair kambing Boer. Jurnal Ternak Tropika. 18 (1):58-68.

Ax, R., M. Dally, B. Didion, R. Lenz, C. Love, D. Varner, Hafez, and M. Bellin. 2008. Semen Evaluation. In Reproduction in Farm Animal $\left(7^{\text {th }}\right.$ edition). Edited by Hafez, E.S.E. Co. Director. Reproductive Health Kiawah Island. South Carolina. USA: 365-370.

Aziz, A. F., M. A. Salim, N. Isnaini, A.P. A. Yekti, dan T. Susilawati. 2018. Pengaruh pengencer air kelapa tua yang berbeda varietas terhadap kualitas semen cair kambing Boer pada penyimpanan $3-5^{\circ} \mathrm{C}$. Jurnal Ilmu-Ilmu Peternakan. 28(2):112 - 120.

Ducha, N., T. Susilawati, Aulanni'am, dan S. Wahjuningsih. 2013. Motilitas dan viabilitas spermatozoa sapi Limousin selama penyimpanan pada refrigerator dalam pengencer CEP-2 dengan suplementasi kuning telur. Jurnal Kedokteran Hewan. 7 (1): 5-8.

Farapati dan S. Sayogo. 2014. Air kelapa muda pengaruhnya terhadap tekanan darah. Cermin Dunia Kedokteran. 41(12): 896-900.

Garner, D.L. and E.S.E. Hafez. 2008. Spermatozoa and Seminal Plasma. In Reproduction in Farm Animals $\left(7^{\text {th }}\right.$ edition). Edited by E.S.E Hafez and B. Hafez. 2008. Lippincott \& Williams. Baltimore, Marryland. USA: 96-109.

Ismaya. 2014. Bioteknologi Inseminasi Buatan pada Sapi dan Kerbau. Gadjah Mada University Press. Yogyakarta. ISBN 979-420-848-5.

Kewilaa, A. I., Y. S. Ondho, dan E. T. Setiatin. 2014. Efisiensi penambahan kuning telur dalampembuatan pengencer air kelapa-kuning telur terhadap kualitas spermatozoa pada semen cair Domba Ekor Tipis (DET). Agriland. 2 (2): 1-12.

Muhammad, D., T. Susilawati, S. Wahjuningsih. 2016. Pengaruh penggunaan CEP-2 dengan suplementasi kuning telur terhadap kualitas spermatozoa sapi FH (Frisian Holstein) kualitas rendah selama penyimpanan suhu $4-5^{\circ} \mathrm{C}$. Jurnal Ternak Tropika. 17 (1): 66-76.

Mugiyati, Salin M. A., N. Isnaini, dan T. Susilawati. 2017. Pengaruh air kelapa merah yang muda dan tua sebagai pengencer terhadap kualitas semen kambing Boer selama penyimpanan dingin. Jurnal Ternak Tropika. 18(1): 20-26. 
Nikbakht, R. and N. Saharkhiz. 2011. The influence of sperm morphology, total motile sperm count of semen and the number of motile sperm inseminated in sperm samples on the success of intrauterine insemination. International Journal of Fertility and Sterility. 5(3): 168-173.

Salim, M. A., M. N. Ihsan, N. Isnaini, A.P.A. Yekti, and T. Susilawati. 2018. Quality of Boer goad liquid semen on different coconut water diluent (Cocos nucifera) during cold storage. Asian Journal of Microbiology, Biotechnology \& Environmental Sciences. 20: 150-157.
Susilawati, T. 2011. Spermatology. Universitas Brawijaya (UB) Press. Malang. ISBN 978-602-8960-04-5.

Susilawati, T., D. Ratnawati, N. Isnaini, Kuswati and A. P. A. Yekti. 2018. Character of liquid semen motility in various diluents on Balinese cattle during cold storage. Asian Journal of Microbiology, Biotechnology \& Environmental Sciences. 20 (1): 166172.

Vigliar, R., V. L. Sdepanian, U. FagundesNeto. 2006. Biochemical profile of coconut water from coconut palms planted in an Inland Region. Journal de Pediatria. 82(4): 308-312. 